\title{
Modeling the Relative Humidity in New Halfa Agricultural Scheme (Sudan)
}

\author{
Tariq Mahgoub Mohamed ${ }^{1 *}$, Hisham Mohamed Hassan ${ }^{2}$, Mahmoud Abdelrahim Abdelgiom ${ }^{3}$ \\ ${ }^{1,3}$ Department of Civil Engineering, Jazan University, Jazan, KSA \\ ${ }^{2}$ Department of Econometrics, University of Khartoum
}

*Corresponding Author: Tariq Mahgoub Mohamed, Department of Civil Engineering, Jazan University, Jazan, KSA

\begin{abstract}
In this paper, linear stochastic approach with the Seasonal Autoregressive Integrated Moving Average (SARIMA) based methods are used to model relative humidity for New Halfa Agricultural Production Scheme. Relative humidity has main influences on the crop production, crop protection and storage and this factor should be modeled for future design purposes. The realization analyzed spans from 2000 to 2014. An inspection of the original series confirms a yearly seasonal pattern. The results of PhillipsPerron (PP) test shows that this series is not stationary. This non-stationarity was removed using first order seasonal differencing (i.e. twelve-monthly) prior to the selection of the model. The SARIMA $(1,0,0) \times(0,1,1) 12$ model was choose as the most suitable for modeling monthly relative humidity for New Halfa Agricultural Production Scheme.
\end{abstract}

Keywords: Relative Humidity, Stochastic models, New Halfa Agricultural Production Scheme, Sudan

\section{INTRODUCTION}

The construction of the Aswan High Dam, in the early 1960's, was a huge disaster to the Sudanese Nubians living in the border town of Wadi Halfa and the neighboring villages. The dam buried the oldest civilization land in Africa which back to more than 3000 B.C under its water. Consequently, more than 50,000 Sudanese Nubians (Halfawien) had to be relocated to new villages in northeastern Sudan near to the Atbara River called New Halfa, about 850 kilometers southeast of their original homes [1,2]. It is one of the largest centrally planned and executed human relocations in the world history [3]. Several observers of the exodus operations alarm that a large amount of Nubian's mineral wealth might have been obscured in the lake waters. But the humanitarian factor in the evacuation of Nubians to their new residences is definitely the worst one.

The New Halfa Agricultural Production Scheme is constructed to residence the displaced Nubians. The scheme has been produced different crops like cotton, wheat, sugar and sorghum. It draws its water from the Khashm al Girba dam on the Atbara River.

Crops production is mainly affected by many climatic variables, such as, precipitation, temperature, relative humidity and solar radiation. Relative humidity directly influences the water relations of plant and indirectly affects leaf growth, photosynthesis, pollination, occurrence of diseases and finally economic yield [4]. Modeling and forecasting relative humidity is predominant factor for the agricultural operations and for future design purposes.

SARIMA modes have been extensively used to model different types of seasonal time series. For example, Nasiru and Solomon [5] applied a SARIMA model to forecast short term inflation in Ghana. Ette [6] used an Additive SARIMA model for daily exchange rates of the Malaysian Ringgit and Nigerian Naira. Bazrafshan et al. [7] found that the application of SARIMA modeling was appropriate for the forecasting of hydrological drought in the Karkheh Basin, Iran. Arumugam and Anithakumari, [8] fitted SARIMA $(2,1,2) \times(1,1,1)_{12}$ model to forecast natural rubber production in India. Li etal [9] proposed SARIMA $(0,1,1)(0,1,1)_{12}$ model for forecasting outpatient amount in China. Kibunja et al. [10] applied a SARIMA $(1,0,1) \mathrm{x}(1,0,0) 12$ model to monthly rainfall in Mt. Kenya region, Kenya. Mohamed and Etuk [11] used a SARIMA $(2,0,0) \times(0,1,1)_{12}$ to predict monthly flow of Rahad River, Sudan. These are just to mention a few. 
This work applied the seasonal autoregressive integrated moving average (SARIMA) approach to simulate the monthly relative humidity for the New Halfa Agricultural Production Scheme.

\section{MATERIALS AND Methods}

\subsection{Study Area and Data}

The New Halfa Agricultural Production Scheme is bounded between latitudes $14.75^{\circ} \mathrm{N}$ and $16.00^{\circ} \mathrm{N}$ and longitude $35.00^{\circ} \mathrm{E}$ and $36.00^{\circ} \mathrm{E}$ with altitude 450 masl. It covers an area of about half a million feddans of which about eighty percent was under irrigation from Khashm al Girba dam on the Atbara River. It is characterized by annual rainfall of [78 - 543] mm during the period from 1940-2004 [12].

Climate Forecast System Reanalysis (CFSR) of the National Centers for Environmental Prediction (NCEP) readily gives climate data for any position on the earth between 1979 and 2014. Numerous studies used the CFSR data set as a source for their works [13,14,15,16,17]. The CFSR data (globalweather.tamu.edu) were obtained for the entire region (bounding box: latitude 14.0-17.0 $\mathrm{N}$ and longitude $34.0-37.0^{\circ}$ E) before choosing the closest station for the scheme. It includes temperature, daily rainfall, wind speed and relative humidity.

\subsection{Modeling by SARIMA Methods}

A time series is said to be stationary if it has constant mean and variance. A stationary time series can be modeled in several ways: an autoregressive (AR) process, a moving average (MA) process, or an autoregressive and moving average (ARMA) process. Although, an ARMA model deal with stationary data, ARMA models can be applied to non-stationary series by permitting differencing of data series. These models are called autoregressive integrated moving average (ARIMA) models. A time series may have non-seasonal and seasonal characteristics.

The general structure of non-seasonal ARIMA model is AR to order $p$ and MA to order $q$ and operates on $d$ th difference of the time series $X_{t}$; therefore a model of the ARIMA family is classified by three parameters $(p, d, q)$ that can have zero or positive integral values. The general non-seasonal ARIMA model may be written as

$\phi(B) \nabla^{d} X_{t}=\theta(B) \varepsilon_{t}$

Where:

$\phi(B)$ and $\theta(B)=$ polynomials of order $p$ and $q$, respectively.

$\phi(B)=\left(1-\phi_{1} B-\phi_{2} B^{2}-\cdots \phi_{P} B^{p}\right)$

and

$\theta(B)=\left(1-\theta_{1} B-\theta_{2} B^{2}-\cdots \theta_{q} B^{q}\right)$

Commonly time series have a seasonal part that repeats every $s$ observations. For monthly observations $s=12$ (12 in 1 year), for quarterly observations $s=4$ (4 in 1 year). Box et al, [18] has generalized the ARIMA model to deal with seasonality, and define a general multiplicative seasonal ARIMA model, which are generally known as SARIMA models. In short form the SARIMA model expressed as ARIMA $(p, d, q) \times(P, D, Q) s$, which is written as

$\phi_{p}(B) \Phi_{p}\left(B^{s}\right) \nabla^{d} \nabla_{s}^{D}\left(X_{t}\right)=\theta_{q}(B) \Theta_{Q}\left(B^{s}\right) \varepsilon_{t}$

Where $p$ is the order of non-seasonal autoregression, $d$ the number of regular differencing, $q$ the order of non-seasonal MA, $P$ the order of seasonal autoregression, $D$ the number of seasonal differencing, $Q$ the order of seasonal MA, $s$ is the length of season, $\Phi_{p}$ and $\Theta_{q}$ are the seasonal polynomials of order $P$ and $Q$, respectively.

SARIMA models development consists of the next three steps: model identification, parameters estimation and diagnostic checking. The model that gives the minimum Akaike Information Criterion (AIC) [19] is chosen as best fit model. The statistical and econometric software Eviews-9 was applied for the analytical work.

\section{RESULTS AND DISCUSSION}

The time plot of the monthly relative humidity in Figure 1 shows that there is a seasonal pattern in the series and the series is non-stationary. The Phillips-Perron (PP) test proved the non-stationarity of the series, as shown in Table 1. The data is seasonal of period 12 months and must therefore be differenced by one seasonal degree of differencing to attain stationary . The PP test was done again 
on the seasonally differenced data. The results of the test adjudge that the differenced series is stationary, Table 2.

Figure 2 shows the ACF and PACF plots of the data after we take seasonal difference. It appears that the majority of the seasonality is disappeared and the data became stable. The autocorrelation structure in Figure 2 suggests many models. The suggested models, the Akaike Information Criterion (AIC) are shown in Table 3. Clearly, model SARIMA $(1,0,0) \mathrm{x}(0,1,1)_{12}$ has the smallest values of AIC in that case one would temporarily have this model.

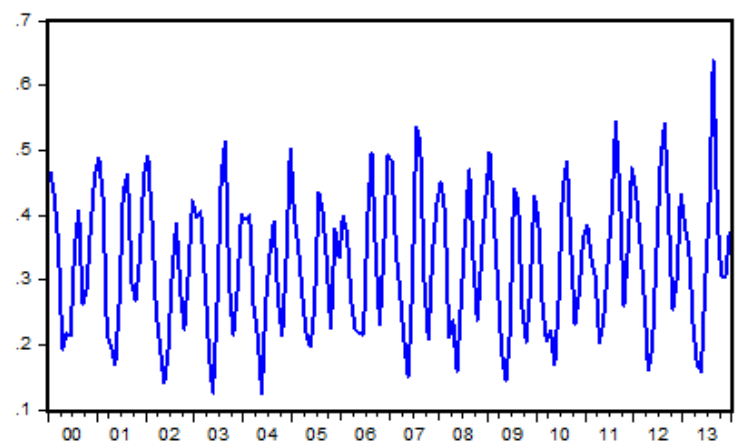

Figure1. Monthly relative humidity for New Halfa Scheme [2000-2013]

Table1. Unit root test of the monthly flow data

\begin{tabular}{|c|c|c|}
\hline Test & Static & P-value \\
\hline Phillips-Perron & -1.4866 & 0.1280 \\
\hline
\end{tabular}

Table2. Unit root test of the differenced data

\begin{tabular}{|c|c|c|}
\hline Test & Static & P-value \\
\hline Phillips-Perron & -9.1880 & 0.0000 \\
\hline
\end{tabular}

\begin{tabular}{|c|c|c|c|c|c|c|}
\hline Autocorrelation & Partial Correlation & & $A C$ & PAC & Q-Stat & Prob \\
\hline $1 \square$ & $1 \square$ & 1 & 0.287 & 0.287 & 13.117 & 0.000 \\
\hline 1 & 10 & 2 & 0.039 & -0.047 & 13.361 & 0.001 \\
\hline 10 & 11 & 3 & -0.034 & -0.035 & 13.550 & 0.004 \\
\hline I & 1 & 4 & 0.033 & 0.060 & 13.723 & 0.008 \\
\hline 10 & 101 & 5 & -0.036 & -0.069 & 13.940 & 0.016 \\
\hline ים ' & 1 & 6 & 0.095 & 0.135 & 15.425 & 0.017 \\
\hline$\overline{1}_{1}$ & 1 & 7 & 0.055 & -0.007 & 15.924 & 0.026 \\
\hline 101 & 1 & 8 & -0.061 & -0.095 & 16.541 & 0.035 \\
\hline 1 & ים & 9 & 0.019 & 0.095 & 16.601 & 0.055 \\
\hline 1 & 1 & 10 & 0.045 & 0.000 & 16.947 & 0.076 \\
\hline 1 1 & 1 & 11 & -0.066 & -0.093 & 17.677 & 0.089 \\
\hline 1 & ， & 12 & -0.519 & -0.531 & 63.773 & 0.000 \\
\hline 미 & إ' 1 & 13 & -0.215 & 0.094 & 71.757 & 0.000 \\
\hline 11 & ， 号 & 14 & 0.019 & 0.154 & 71.822 & 0.000 \\
\hline ומ ו & $\Gamma_{1}$ & 15 & 0.071 & -0.022 & 72.699 & 0.000 \\
\hline 1 & ון & 16 & 0.065 & 0.071 & 73.448 & 0.000 \\
\hline ים ו ו & 1 & 17 & 0.096 & 0.025 & 75.079 & 0.000 \\
\hline 10 & 1 & 18 & -0.070 & 0.036 & 75.946 & 0.000 \\
\hline 1 & 1[1 & 19 & -0.105 & -0.068 & 77.915 & 0.000 \\
\hline ול ו & 1 & 20 & 0.081 & 0.038 & 79.098 & 0.000 \\
\hline $1{ }_{1}$ & i i & 21 & 0.010 & -0.014 & 79.118 & 0.000 \\
\hline 1 & 1 & 22 & -0.041 & -0.006 & 79.429 & 0.000 \\
\hline 11 & 1 & 23 & -0.026 & -0.032 & 79.559 & 0.000 \\
\hline 尚 & 무. & 24 & 0.146 & -0.182 & 83.519 & 0.000 \\
\hline . & 1 & 25 & 0.132 & 0.133 & 86.794 & 0.000 \\
\hline 1 & 1 & 26 & 0.025 & 0.040 & 86.916 & 0.000 \\
\hline 11 & 11 & 27 & -0.022 & -0.011 & 87.013 & 0.000 \\
\hline ه' & $\square_{1}$ & 28 & -0.220 & -0.260 & 96.305 & 0.000 \\
\hline 미 । & 1 1 & 29 & -0.181 & 0.020 & 102.67 & 0.000 \\
\hline 1 & i I & 30 & -0.079 & -0.019 & 103.88 & 0.000 \\
\hline 1 & 10 & 31 & 0.065 & -0.059 & 104.71 & 0.000 \\
\hline I [ & 111 & 32 & -0.078 & -0.018 & 105.93 & 0.000 \\
\hline 1 & 10 & 33 & -0.045 & -0.035 & 106.35 & 0.000 \\
\hline 1 & 1 & 34 & -0.110 & -0.083 & 108.78 & 0.000 \\
\hline 11 & 17 & 35 & -0.032 & 0.004 & 108.99 & 0.000 \\
\hline 10 & 10 & 36 & -0.073 & -0.079 & 110.08 & 0.000 \\
\hline
\end{tabular}

Figure2. ACF and PACF plots after one seasonal difference 
Following the selection of the best model using the AIC criteria, estimation of the parameters was done. The value of the parameters, associated standard errors, $t$ - statistic and $p$-values are accessible in Table 4. The results verified that the parameters are significant since their $p$-values are lesser than 0.05. All the absolute values of the inverted AR and MA roots are smaller than one; hence the model is stationary and invertible.

Once the best model is selected, the Box-Jenkins methodology requires examining the residuals of the model. The residuals must behave like Gaussian white noise, which is appearing random, homoscedastic and normal [18]. Many confirmation tests were used on the residual series. The selected tests are the Box-Ljung test, the Durbin-Watson Statistic test, the Jarque-Bera test and ARCH LM test. These tests are discussed in the next paragraphs.

The residuals autocorrelation function (RACF) and partial autocorrelation function (RPACF) are valuable tools to judge the presence of correlation between the residuals. The ACF and PACF of residuals of the model are shown in Figure 3. All values of the RACF and RPACF lie within the confidence limits. The figure supports the absence of significant correlation between the residuals.

Table3. Comparison of the proposed Models

\begin{tabular}{|c|c|c|c|}
\hline Variable & Station & Model & AIC \\
\hline \multirow{6}{*}{$\begin{array}{c}\text { Monthly Relative } \\
\text { Humidity }\end{array}$} & \multirow[t]{6}{*}{ New Halfa Scheme } & SARIMA $(1,0,1) \mathrm{X}(0,1,1)_{12}$ & -3.285 \\
\hline & & SARIMA $(1,0,0) \mathrm{X}(0,1,1)_{12}$ & -3.303 \\
\hline & & SARIMA(1,0,1)X(1,1,1) 12 & -3.272 \\
\hline & & SARIMA $(1,0,1) \mathrm{X}(1,1,0)_{12}$ & -3.199 \\
\hline & & $\operatorname{SARIMA}(0,0,1) \mathrm{X}(1,1,1)_{12}$ & -3.273 \\
\hline & & $\operatorname{SARIMA}(0,0,1) \mathrm{X}(1,1,0)_{12}$ & -3.206 \\
\hline
\end{tabular}

Table4. Estimation of the SARIMA $(1,0,0) \times(0,1,1) 12$ model

\begin{tabular}{lrlrr}
\hline \hline \multicolumn{1}{c}{ Variable } & Coefficient & Std. Error & t-Statistic & Prob. \\
\hline \multicolumn{1}{c}{ AR(1) } & 0.337454 & 0.083119 & 4.059898 & 0.0001 \\
MA(12) & -0.736566 & 0.071517 & -10.29913 & 0.0000 \\
SIGMASQ & 0.001949 & 0.000199 & 9.808004 & 0.0000 \\
\hline \hline R-squared & 0.440774 & Mean dependent var & -0.000127 \\
Adjusted R-squared & 0.433463 & S.D. dependent var & 0.059224 \\
S.E. of regression & 0.044577 & Akaike info criterion & -3.303220 \\
Sum squared resid & 0.304033 & Schwarz criterion & -3.244569 \\
Log likelihood & 260.6512 & Hannan-Quinn criter. & -3.279398 \\
Durbin-Watson stat & 2.010565 & & & \\
\hline \hline Inverted AR Roots & .34 & & & \\
Inverted MARoots & .97 & $.84+.49 \mathrm{i}$ & $.84-.49 \mathrm{i}$ & $.49-.84 \mathrm{i}$ \\
& $.49+.84 \mathrm{i}$ & $.00-.97 \mathrm{i}$ & $-.00+.97 \mathrm{i}$ & $-.49-.84 \mathrm{i}$ \\
& $-.49+.84 \mathrm{i}$ & $-.84+.49 \mathrm{i}$ & $-.84-.49 \mathrm{i}$ & -.97 \\
\hline \hline
\end{tabular}

\begin{tabular}{|c|c|c|c|c|c|c|}
\hline Autocorrelation & Partial Correlation & & $A C$ & PAC & Q-Stat & Prob \\
\hline 11 & 11 & & -0.010 & -0.010 & 0.0174 & \\
\hline $1 \mathrm{~b}$ & 10 & 2 & 0.044 & 0.044 & 0.3309 & \\
\hline 14 & 1) & & -0.027 & -0.026 & 0.4463 & 0.504 \\
\hline & 1]. & & 0.012 & 0.009 & 0.4687 & 0.791 \\
\hline 1' & 1 & & -0.098 & -0.096 & 2.0308 & 0.566 \\
\hline 1日 & , & & 0.106 & 0.104 & 3.8855 & 0.422 \\
\hline 15 & 10 & & -0.066 & -0.057 & 4.5953 & 0.467 \\
\hline 1 & (4) & & -0.054 & -0.068 & 5.0746 & 0.534 \\
\hline 1 & 4 & 9 & 0.032 & 0.046 & 5.2505 & 0.629 \\
\hline$i$ & 1 & 10 & 0.046 & 0.039 & 5.6146 & 0.690 \\
\hline i & & 11 & 0.112 & 0.130 & 7.7299 & 0.562 \\
\hline 15 & (4) & 12 & -0.083 & -0.113 & 8.9117 & 0.541 \\
\hline 1 & 1 1 & 13 & -0.043 & -0.052 & 9.2358 & 0.600 \\
\hline 10 & 当 & 14 & 0.128 & 0.170 & 12.072 & 0.440 \\
\hline 1 & in & 15 & 0.083 & 0.077 & 13.264 & 0.428 \\
\hline 1 & 1 & 16 & -0.059 & -0.069 & 13.867 & 0.460 \\
\hline יוp & 1 & 17 & 0.069 & 0.030 & 14.708 & 0.473 \\
\hline 단 & י & 18 & -0.121 & -0.085 & 17.312 & 0.366 \\
\hline ב & 면 & 19 & -0.151 & -0.127 & 21.411 & 0.208 \\
\hline 1 & & 20 & 0.078 & 0.056 & 22.525 & 0.210 \\
\hline I & i. & 21 & 0.020 & 0.008 & 22.599 & 0.255 \\
\hline id & idi & 22 & -0.077 & -0.048 & 23.698 & 0.256 \\
\hline 1 & 11 & 23 & 0.003 & -0.007 & 23.700 & 0.308 \\
\hline ים י י & 1 只 & 24 & 0.095 & 0.091 & 25.386 & 0.279 \\
\hline י & 1 & 25 & 0.049 & 0.045 & 25.830 & 0.309 \\
\hline , & i & 26 & 0.079 & 0.037 & 27.025 & 0.303 \\
\hline 1 & & 27 & 0.040 & 0.067 & 27.335 & 0.339 \\
\hline ㅁ. & E. & 28 & -0.177 & -0.205 & 33.389 & 0.151 \\
\hline , & 11 & 29 & -0.040 & -0.018 & 33.699 & 0.175 \\
\hline ㄷ. & di & 30 & -0.165 & -0.156 & 39.053 & 0.080 \\
\hline 1. & 11 & 31 & 0.031 & -0.025 & 39.240 & 0.097 \\
\hline 1대 1 & 111 & 32 & -0.075 & -0.023 & 40.344 & 0.098 \\
\hline 111 & 1 1 1 & 33 & -0.013 & 0.026 & 40.378 & 0.121 \\
\hline ' & 14 & 34 & -0.098 & -0.089 & 42.308 & 0.105 \\
\hline 1 & 14 & 35 & 0.042 & -0.056 & 42.668 & 0.121 \\
\hline i I & b. & 36 & -0.016 & 0.056 & 42.722 & 0.145 \\
\hline
\end{tabular}

Figure3. ACF and PACF plots for SARIMA $(1,0,0) x(0,1,1)_{12}$ Residual 
The Ljung-Box test is applied for checking independence of residual. From Figure 3, the goodness of fit values for the autocorrelations of residuals from the model up to lag 36 was greater than 0.05 . The result proves the acceptance of the null hypothesis of model adequacy at the 5\% significance level and the set of autocorrelations of residuals was considered white noise.

The Durbin-Watson (DW) statistic measures the serial correlation in the residuals. If the residuals are not correlated, the Durbin-Watson statistic will be 2 [20]. The Durbin-Watson test statistic value in Table 4 is found to be 2.0105 , which does not deviate from 2 by more than 0.0105 . Hence, there is no serial correlation between the residuals.

The result for the Jarque-Bera tests show that the residuals are normally distributed as the skewness is close to zero and kurtosis close to 3. (See Figure 4: JB $=2.242, p$ value $=0.3258$ ). Homoscedasticity is the expression applied to identify that the variance of the residual in each observation is constant. In this work, we apply ARCH LM test. The test statistics value of ARCH LM test for the homoscedasticity of the residuals is presented in Table 5. The $p$-value for the test is greater than 0.05 , which indicating that the residual variance is constant.

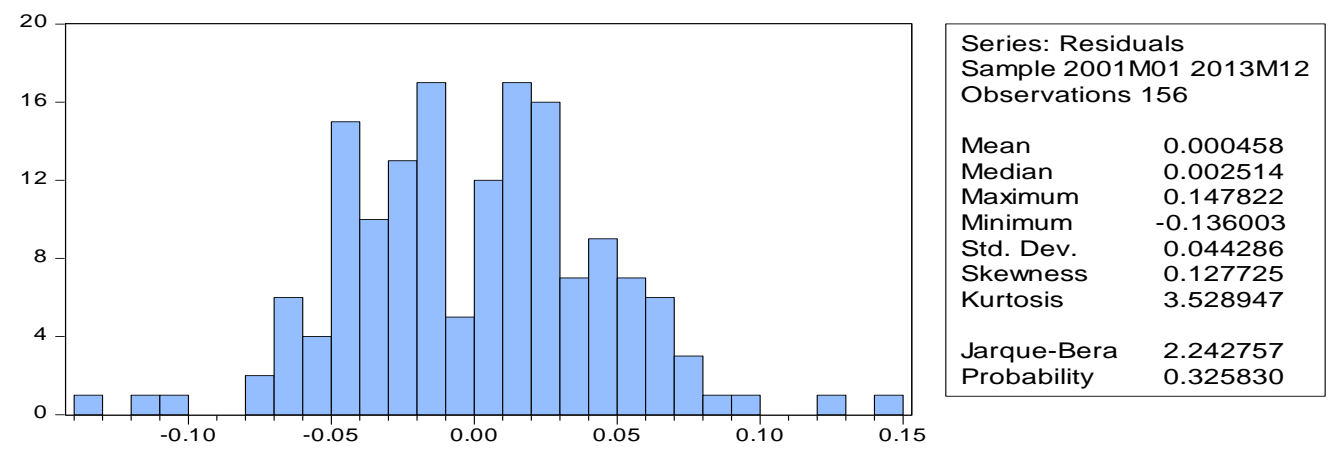

Figure4. Histogram of the Residuals

Table5. ARCH test

\begin{tabular}{|c|c|c|c|}
\hline F-statistic & 0.376934 & Prob. F(2,151) & 0.6866 \\
\hline Obs*R-squared & 0.765025 & Prob. Chi-Square(2) & 0.6821 \\
\hline
\end{tabular}

\section{CONClusion}

In this paper, linear stochastic approach with the Seasonal Autoregressive Integrated Moving Average (SARIMA) based methods are used to model relative humidity for New Halfa Agricultural Production Scheme, Sudan.

The time plot of the monthly relative humidity shows that there is a seasonal pattern in the series and the series is non-stationary. This non-stationarity was removed using first order seasonal differencing (i.e. twelve-monthly) prior to the selection of the model. The SARIMA $(1,0,0) \times(0,1,1) 12$ model was choose as the most suitable for modeling monthly relative humidity for New Halfa Agricultural Production Scheme.

\section{REFERENCES}

[1] Sorbo,G.M, (1985). Tenants and Nomads in Eastern Sudan: A Study of Economic Adaptations in the New Halfa Scheme, Scandinavian Institute of African Studies, Uppsala.

[2] Salman, M.A.(2010). Water Resources in the Sudan North-South Peace Process: Past Experience and Future Trends, African Yearbook of International Law, 299-328.

[3] Dafalla H.,(1975) The Nubian Exodus, C. Hurst and Company, London.

[4] http://agritech.tnau.ac.in/agriculture/agri_agrometeorology_relativehumidity.html

[5] Nasiru, S. \& Solomon, S. (2012). Empirical Approach to Modeling and Forecasting Inflation in Ghana. Current Research Journal of Economic Theory, 4(3), 83-87.

[6] Etuk, EH. An Additive SARIMA Model for Daily Exchange Rates of the Malaysian Ringgit (MYR) and Nigerian Naira (NGN). International Journal of Empirical Finance, 2014, 2(4): 193-201.

[7] Bazrafshan, O., Salajegheh, A., Bazrafshan, J., Mahdavi, M. and Marj, A.F. (2015) 'Hydrological drought forecasting using ARIMA models (a case study: Karkheh Basin)', Ecopersia, Vol. 3, No. 3, pp.1099-1117.

[8] Arumugam, P., and Anithakumari, V. (2013). SARIMA model for Natural Rubber production in India. International Journal of Computer Trends and Technology (IJCTT), Vol. 4, No. 8, pp. 2480-2484. 
[9] Xiaosheng Li,Chunliu Ma,Haike Lei \&Haixia Li . Applications of SARIMA Model in Forecasting Outpatient Amount. Chinese Medical Record English Edition, Volume 1, 2013 - Issue 3, Pages 124-128. https://doi.org/10.3109/23256176.2013.798456

[10] Kibunja, H. W., Kihoro , J.M., Orwa , G.O., Yodah , W.O., (2014), Forecasting Precipitation Using SARIMA Model: A Case Study of Mt. Kenya Region, Mathematical Theory and Modeling, Vol.4, No.11, pp:50-58.

[11] Mohamed, T.M., Etuk, E.H, (2017). Application of linear stochastic models to monthly streamflow data of Rahad River, Sudan, Int. J. Hydrology Science and Technology, 7(2), 197-212.

[12] [12] Elhag, MM. Causes and Impact of Desertification in the Butana Area of Sudan. Ph. D. Thesis, University of Free State, South Africa, pp. 171, 2006.

[13] Fuka, D,R etal (2013)Using the climate forecast system reanalysis as weather input data for watershed models , Hydrol.Process, Wiley online liberary.

[14] Diro, G. T., Grimes, D. I. F., Black, E., O’Neill, A., and PardoIguzquiza, E. (2009) Evaluation of reanalysis rainfall estimates over Ethiopia, Int. J. Climatol., 29, 67-78.

[15] Yu, M., Chen, X., Li, L., Bao, A., and Paix, M. J. D. L.(2011) Streamflow Simulation by SWAT Using Different Precipitation Sources in Large Arid Basins with Scarce Raingauges, Water Resour. Manage. 25, 2669-2681.

[16] Roth, V and Lemann T, Comparing CFSR and conventional weather data for discharge and soil loss modelling with SWAT in small catchments in the Ethiopian Highlands, Hydrol. Earth Syst. Sci., 20, 921934, 2016, doi: 10.5194/hess-20-921-2016

[17] Dile, Y T and Raghavan S, 2014. Evaluation of CFSR Climate Data for Hydrologic Prediction in DataScarce Watersheds: An Application in the Blue Nile River Basin. Journal of the American Water Resources Association (JAWRA) 1-16. DOI: 10.1111/jawr.12182

[18] Box, G.E.P., Jenkins, G.M., Reissel, G.C., (1994) Time Series Analysis Forecasting and Control, 3rd edition, Prentice Hall, USA.

[19] Akaike, H.,(1974) “A New look at the statistical model identification, " IEEE Trans Automatic Control, AC- 19:716-723.

[20] Montgomery, D.C., Peck, E.A., Vining, G.G.,( 2006) Introduction to Linear Regression Analysis. 4th Edition, John Wiley \& Sons, UK.

Citation: Tariq Mahgoub Mohamed, et.al, "Modeling the Relative Humidity in New Halfa Agricultural Scheme (Sudan)", International Journal of Research in Environmental Science (IJRES), vol. 5, no. 2, pp. 23-28, 2019. Available: DOI: http://dx.doi.org/10.20431/2454-9444.0502004

Copyright: (C) 2019 Authors. This is an open-access article distributed under the terms of the Creative Commons Attribution License, which permits unrestricted use, distribution, and reproduction in any medium, provided the original author and source are credited. 